\title{
Self-assembling of Chimeric Mussel-inspired Bio- adhesives Originated from Mytilus Californianus and Anabaena Flos-aquae: A New Approach to Develop Underwater Adhesion
}

Hamidreza Iranpour

Pasteur Institute of Iran

Hossein Shahsavarani

Pasteur Institute of Iran

Seyed Nezamedin Hosseini

Pasteur Institute of Iran

Hani Hosseini Far

Murdoch Children's Research Institute

Sareh Zhand

University of Technology Sydney

Mahdi Mohammadi Ghanbarlou

Pasteur Institute of Iran

Saeid Bouzari

Pasteur Institute of Iran

Mohammad Ali Shokrgozar ( $\nabla$ shokrgozar1965@gmail.com )

Pasteur Institute of Iran

\section{Research Article}

Keywords: Mussel foot protein, Gas vesicle Protein A, Self-assemble, Underwater adhesive

Posted Date: March 17th, 2021

DOI: https://doi.org/10.21203/rs.3.rs-294097/v1

License: (c) (i) This work is licensed under a Creative Commons Attribution 4.0 International License. Read Full License 
Title: Self-assembling of Chimeric Mussel-inspired Bio-adhesives originated from Mytilus Californianus and Anabaena flos-aquae: A New Approach to Develop Underwater Adhesion

Hamidreza Iranpour, ${ }^{\text {a,b,h }}$ Hossein Shahsavarani, ${ }^{\text {a,g }}$ Seyed Nezamedin Hosseini, ${ }^{c}$ Hani Hosseini Far, ${ }^{\mathrm{d}, \mathrm{e}}$ Sareh zhand, ${ }^{\mathrm{f}}$ Mahdi Mohammadi Ghanbarlou, ${ }^{\mathrm{a}, \mathrm{h}}$ Saeid Bouzari, ${ }^{\text {b* }}$ Mohammad Ali Shokrgozar ${ }^{\text {h* }}$

${ }^{a}$ Laboratory of Regenerative Medicine and Biomedical Innovations, Pasteur Institute of Iran, Tehran, Iran

${ }^{\mathrm{b}}$ Molecular Biology Department, Pasteur Institute of Iran, Tehran, Iran

'Pasteur Institute of Iran, Department of Hepatitis B Vaccine Production, Production and Research Complex, Tehran-Karaj highway, 3159915111 Tehran, Iran

${ }^{\mathrm{d}}$ Murdoch Children's Research Institute, Australia

${ }^{e}$ Department of Paediatrics, University of Melbourne, Australia

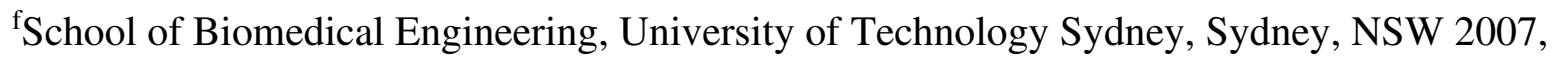
Australia

${ }^{g}$ Department of Cellular and Molecular Sciences, Faculty of Bioscience and Biotechnology, Shahid Beheshti University, Tehran, Iran

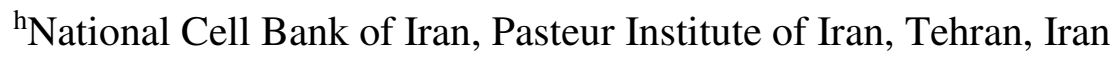

Running Title: Novel Mussel-inspired Adhesive with amyloid features

*Address correspondence to shokrgozar1967@gmail.com and saeidbouzari@yahoo.com. 
*Present address: Mohammad Ali Shokrgozar, Pasteur Institute of Iran, Tehran, Iran.

Saeid Bouzari and Mohammad Ali Shokrgozar contributed equally to this work. Author order was determined on the basis of seniority.

\begin{abstract}
:
Bio-adhesives play a pivotal role in a wide range of medical applications. However, there are some problems about their application in varied $\mathrm{pH}$ values and low adhesion force under wet conditions. Here, we report new recombinant fusion protein achieved by mussel foot proteins (Mfps) of Mytilus Californianus and gas vesicle protein A (GvpA) of Anabaena flos-aquae by genetic engineering methods. These chimeric proteins self-assembled into $ß$-sheet rich fibres because of GvpA amyloid structure. Also, their adhesion forces were significantly increased especially in alkaline environment based on Mfp-3 and Mfp-5. This study illustrates that copolymer of Mfp-5GvpA:GvpA-Mfp-3 can be used as an underwater sturdy adhesive with tolerance to autooxidation, especially at basic conditions.
\end{abstract}

Keywords: Mussel foot protein, Gas vesicle Protein A, Self-assemble, Underwater adhesive 
Introduction:

Naturally, bio-inspired adhesives originated from mussel, barnacles, Notaden frogs and gecko have had extensive interest among scientists due to being water-based adhesive $\mathrm{e}^{1-5}$. On the one hand, the presence of large quantities of Dihydroxyphenylalanine (DOPA) known to encourage adhesion on wet surfaces ${ }^{6}$ is a special characteristic of Mussel Foot Proteins ${ }^{7}$. Tremendous features in Mussel Foot Proteins (Mfp-3 and Mfp-5) such as resistance in heavy water flow just as changes in temperature and saltiness are so impressive for designing a superglue. Two cited proteins contain highest DOPA (in byssal plaque of Mytilus californianus) in their protein structures ${ }^{8}$.

On the other hand, amyloids as bio-inspired adhesives can make novel opening for surface/interface functionalization ${ }^{9}$. The versatility of amyloids have attracted the attention of scientists ${ }^{10}$. In a significant number of pathologies, including neurodegenerative diseases and systemic amyloidosis, amyloid fibrils have been identified ${ }^{11}$. A Polypeptide molecules capable of self-assembly into $B$-sheet rich linear aggregates are amyloidogenic proteins ${ }^{12}$. A $\beta$-hairpin that forms an antiparallel $\beta$-sheet is found in amyloid monomers. Amyloids are versatile proteins for interfacial underwater adhesion. For interfacial underwater adhesion, such fibrillar structures have incredible advantages ${ }^{13}$. A study was conducted regarding the presence of amyloid fibers in Gas vesicle protein A (GvpA) of Anabaena flos-aquae. This protein has some advantages such as tolerance to proteolysis, providing the strength of protein structure and amphiphilic properties ${ }^{14}$.

In our study, we have logically planned for a novel chimeric bioadhesive involving musselinspired adhesive and amyloidogenic protein. For having superglue, Mfp-3 and Mfp-5 have been selected with highest Tyrosine (DOPA-based mussel foot protein) among other Mfps and GvpA single protein as amyloidogenic protein has been chosen from Gas Vesicle wall of Anabaena flosaquae. Also, Mfp-5-GvpA and GvpA-Mfp-3 were built. Due to having self-assembly of GvpA as 
amyloidogenic protein, it is expected that both Mfp-5-CsgA and CsgA-Mfp-3 could self-assemble together into amyloid fibrils with adhesive features by showing DOPA residue on the outside of amyloid scaffold to create copolymers according to previous research work (Figure 1) ${ }^{4}$. They can also build more strength, resistant to proteolysis and protein flexibility and elasticity, achieved by GvpA in chimeric protein ${ }^{14}$. moreover, we have measured force adhesion between these functional chimeric proteins and mica under wet conditions. The impact of varied $\mathrm{pH}$ values on adhesion has been investigated too. We have reached maximum force adhesion at neutral $\mathrm{pH}$ and found that copolymers at alkaline $\mathrm{pH}$ had the most force adhesion. Nonetheless, other approaches have failed to attain underwater adhesion at neutral $\mathrm{pH}^{15,16}$.

Results and discussion:

Expression of recombinant Mfp-5- GvpA and recombinant GvpA-Mfp-3 hybrids:

The results illustrated in this research work match the state-of-the-art chimeric proteins. Formerly, Mfp-5- GvpA and GvpA-Mfp-3 cDNAs were specifically optimized for E. coli (Mfp-3 and Mfp-5 genes from Mytilus californianus and GvpA gene from Anabaena flos-aquae), synthesized (by Biomatik Co., Canada) and inserted into a pET-11a expression vector, and then were transformed into E. coli BL21 (DE3). Induction of Mfp-5-GvpA and GvpA-Mfp-3 recombinant hybrids were performed by IPTG $1 \mathrm{mM}$ but there are not expressed proteins in SDS-PAGE and Western Blotting, which can be due to toxicity of produced recombinant proteins ${ }^{17,18}$. Hence, E. coli BL21-AI have been used as alternative for resolving this problem ${ }^{19,20}$. After the induction of aforementioned recombinant mussel-inspired amyloid hybrids with L-arabinose $0.2 \%$ and IPTG $1 \mathrm{mM}$, cells were grown for 3 hours. Most of the recombinant proteins were expressed as inclusion body (IB) in $E$. coli. Total expressed proteins were analyzed with SDS-PAGE 10\% (Coomassie Brilliant Blue G250 staining) (Figure 3) and Western Blotting (Anti-histidine antibody) (Figure 4). 
Recombinant protein purification:

Protein purification was performed by nickel-containing affinity resin. Recombinant proteins were solubilized by $8 \mathrm{M}$ urea, and they were not bound to nickel resin due to aggregated proteins. Consequently, we have used fresh $6 \mathrm{M}$ guanidine $\mathrm{HCl}(\mathrm{GuHCl})$ (stronger chaotrope than $8 \mathrm{M}$ urea) as denaturant for enhancing the solubility of recombinant proteins, where eventually recombinant proteins could been bound to nickel resin. After purification with nickel-IDA agarose 6\% under danturated conditions (Figure 5), concentration of purified proteins was obtained at 0.7439 $(\mathrm{mg} / \mathrm{mL})$ and $0.8937(\mathrm{mg} / \mathrm{ml})$ for Mfp-5-GvpA and Mfp-3-GvpA proteins through the BCA Protein Assay, respectively.

Modification and confirmation of recombinant protein with tyrosinase treatment qualitatively and quantitatively:

In order to obtain adhesive features, tyrosinase was added to purified proteins (unmodified Mfp5-GvpA and unmodified Mpf-3-GvpA). After the filtration of mussel-inspired adhesives, they have been dialyzed in 5\% acetic acid (to prevent auto-oxidation) at $4{ }^{\circ} \mathrm{C}$. Conversion Tyrosine to DOPA in recombinant GvpA-Mfp-5 and recombinant Mfp-3-GvpA proteins have been detected by redox-cycling nitroblue tetrazolium (NBT) staining, where modified Mfp-5-GvpA and modified Mfp-3-GvpA were stained with a blue-purple band (Figure 6) (Unmodified and modified proteins referred to before and after tyrosinase treatment). For measuring the quantity of this conversion (\% Tyr to DOPA), acid-borate difference spectrum (ABDS) method was utilized (Table 1). According to the protein concentration gained from BCA method, molarity of tyrosine and DOPA were calculated for both Mfp-5-GvpA and Mpf-3-GvpA: M(Tyr) for GvpA-Mfp-3: 0.77252635(mM); M(Tyr) for Mfp-5-GvpA:0.7944(mM); M(DOPA) for GvpA-Mfp-3: 0.09538(mM); M (DOPA) for GvpA-Mfp-5: 0.08973(mM) (supposedly Mfp-5-GvpA and Mpf-3- 
GvpA have 24 and 18 tyrosines, respectively). Then, the percentage of tyrosine converted into dopa were achieved (Table 1).

Congo red staining:

This assay verified amyloidogenic characteristics of GvpA-Mfp-3 and Mfp-5-GvpA (Figure 7).

\section{3-5-Force Adhesion Measurement:}

Atomic force spectroscopy (AFS) was utilized to measure adhesion force of GvpA-Mfp-3, Mfp5-GvpA and copolymer (in both unmodified and modified states) with silica tip on mica surface in a wet environment. Comparative tests with BSA $(\mathrm{F} / \mathrm{R}=3.1 \mathrm{mN} / \mathrm{m})$ and Cell-Tak ${ }^{\mathrm{TM}}(\mathrm{F} / \mathrm{R}=24.7$ $\mathrm{mN} / \mathrm{m}$ ) were conducted as negative and positive control. Modified copolymer ( $\mathrm{F} / \mathrm{R}=157.1938$ $\mathrm{mN} / \mathrm{m})$ and unmodified Mfp-3-GvpA (F/R=17.2744 mN/m) have had the most and least adhesion respectively (at $\mathrm{pH}=5$ ) (Figure 8). In previous studies, it has been shown that recombinant Mfps had adhesive features without tyrosinase treatment, but adhesion force was less than the modified protein with tyrosinase treatment ${ }^{21}$. Nonetheless, unmodified hybrids show more force adhesion than the BSA as a negative control (Unmodified GvpA-Mfp-3=17.2744, Unmodified Mfp-5GvpA=34.0444, and Unmodified GvpA-Mfp3:Mfp-5-GvpA=15.6575). This indicated that, in addition to DOPA, some residues such as lysine and arginine in Mfp-5 have a key role in binding to wet surfaces ${ }^{22-24}$. The adhesion forces of Gvp-A-Mfp-3 and Mfp-5-Gvpa were respectively 2.5 and 2 times more than the cited adhesion force for Mgfp-3A and Mgfp- $5^{21}$. Additionally, force adhesion of Mfp-5-GvpA was almost two times higher than that for mfp-151 measured under identical conditions ${ }^{21}$. Furthermore, adhesion force of modified copolymer (GvpA-Mfp3:Mfp-5GvpA) is 1.5 and 3 times higher than that for modified Mfp-5-GvpA $(99.9368 \mathrm{mN} / \mathrm{m}, \mathrm{P} \leq 0.001)$ and modified GvpA-Mfp-3 (53.6650 mN/m, P $\leq$ 0.0001)(Figure 8). It was supposed that GvpA- 
Mfp3:Mfp-5-GvpA coplolymer widens surface-area-to-volume ratio for DOPA residues to fulfil robust underwater adhesion. This issue was confirmed by previous studies that the self-assembly of GvpA into gas vesicles appears to be regulated in a similar way to that of CsgA and silk spidroin (MaSp1) self-assembly $y^{4,14,25}$.

Also, the force adhesion was evaluated on Mfp-5-CsgA:CsgA-Mfp-3 fibres under wet environment with different $\mathrm{pH}$ values. The order of adhesion strength from highest to lowest is as follows: $\mathrm{pH}=5,7,2.5,12$. In a previous study, AFS was applied for measuring adhesion force of Mfp-5-CsgA-CsgA-Mfp-3 at different pH values ${ }^{4}$. Recent study reported that Mefp5 had onethird of the lower adhesion energy at $\mathrm{pH} 5$ than that at $\mathrm{pH}$ 2.6. Moreover, other studies reveal that the force adhesion of Mfp3 and Mfp5 in basic $\mathrm{pH}$ is virtually eliminated ${ }^{26}$. Oxidation of Dopa residues in alkaline solutions resulted in a reduction in force adhesion (9). For this reason, Gas vesicle protein A (GvpA) was selected as a tolerant agent against auto-oxidation ${ }^{14}$. Notably, we worked on modified copolymer as an strong underwater adhesive at $\mathrm{pH}$ values: 5 and 2.5 , and our modified copolymer reveals a force of adhesion of $\sim 158$ and $122.4850 \mathrm{mN} / \mathrm{m}$; the values that are higher than those in a previous study for under water superglue Mfp- $5^{8}$. A similar pattern of chimeric protein was attained in another research. Mfp3-MaSp1 was chosen as a chimeric mussleinspired adhesive with amyloid features. Adhesion force of this bioadhesive was $55 \mathrm{mN} / \mathrm{m}$, which was lower than our study ${ }^{27}$. In line with previous studies, modified Mfp- $5^{(3)}\left(\mathrm{Mfp}^{(2)}-\operatorname{Intein}^{\mathrm{N}}+\right.$ Intein $^{\mathrm{C}}$-Mfp ${ }^{(1)}$ ) had the force of adhesion $\sim 201 \mathrm{mN} / \mathrm{m}$ at $\mathrm{pH}=5$, the strongest mussel-inspired adhesive among other studies under the same condition. Nevertheless, the force of adhesion was not measured at other $\mathrm{pH}$ values and probably did not have tolerance to auto-oxidation ${ }^{16}$. Overall, our adhesive hybrid mainly showed tolerance to auto-oxidation in comparison with previous studies on another Mfps. In comparison to our study, the adhesion force of our bioadhesive has 
been reinforced at $\mathrm{pH}: 7(152.4125 \mathrm{mN} / \mathrm{m}$ ) (Figure 9). To explain, GvpA is strongly hydrophobic and negatively charged at pH:7 ${ }^{28}$ making it an excellent choice for medical application in physiologic and basic conditions.

Self-assembly of GvpA-Mfp3 and Mfp-5-GvpA (Copolymerization of two recombinant amyloid proteins): phosphate solutions were used to dissolve purified proteins $(\mathrm{pH}=7.2)$ and were altered to $\mathrm{pH}=5.0$. Copolymer fibers (Mfp-5-GvpA:GvpA-Mfp3:) with 5:5 molar ratios have had more adhesion rather than 3:7 and 7:3. According to our study (Figure 10), the (GvpA-Mfp3)-co-(Mfp5GvpA) copolymer hybrid demonstrated the sturdiest underwater adhesion at pH:7 among all former studies on mussel-inspired bioadhesive under the same condition ${ }^{4,27,29-31}$.

All in all, we showed a novel mussel-inspired bioadhesive with amyloidogenic properties including Mfp-5-GvpA and GvpA-Mfp-3. These structures demonstrated strong wet adhesion especially in neutral and alkaline $\mathrm{pH}$. Adhesion force was measured by atomic force spectroscopy with colloidal probe and evaluated in different $\mathrm{pH}$ values. As mentioned, at $\mathrm{pH}=12$, there was the strongest adhesion. For the first time, our mussel-inspired adhesive based on amyloid features of GvpA was utilized as a new chimeric underwater bioadhesive, and had the ability to adhere in variety of $\mathrm{pH}$ values which can be used for a wide range of biomedical applications as a medical device.

Materials and Methods:

Gene design: Having recombinant MFP-3-GvpA and recombinant MFP-5-GvpA, the optimized genes were synthesized artificially by Biomatik corporation (Canada, QC SG180626). Polyhistidine tags were introduced in C-terminal of these gene structures. GS linker was inserted between Mfps and GvpA in recombinant forms. pET-11a was selected as an expression vector. 
Initially, pET11a was cut by two restriction enzymes (BamH1 and Nde1), and then gene constructs were separately inserted between BamHI and NdeI restriction site. Inserted sequences were verified by colony PCR and enzymatic method (BamHI and NdeI enzymes). Colony PCRs were performed with $\mathrm{T} 7$ forward and reverse primers. Sequencing was performed by Biomatik corporation. Plasmid construction are mapped into Figure 2.

Protein Expression: Generally, our procedure is based on methods used in protein expression. It includes the induction of recombinant protein, confirmation of expressed protein, refolding and purification. The recombinant constructs, pET-11a-GvpA-Mfp3, and pET-11a-Mfp5-GvpA, have been transformed in E. coli BL21 AI. Then, these bacteria have been grown to OD600 0.4 in Terrific broth medium consisting of $50 \mathrm{mg} / \mathrm{mL}$ ampicillin at $37^{\circ} \mathrm{C}$. After that, recombinant protein was expressed as inclusion bodies by $0.2 \%$ Arabinose and $1 \mathrm{mM} \mathrm{IPTG}$ at $30^{\circ} \mathrm{C}$ for $3 \mathrm{~h}$.

Cell extract: One liter of the cell culture of E. coli is centrifuged at $5000 \mathrm{~g}$ at $4^{\circ} \mathrm{C}$. The supernatant was removed and the weight of the pellet is determined. Then, Cell lysis buffer (guanidine hydrochloride (GdnHCl, 8M), 50 mM Tris-Cl (pH 8.0), I mM EDTA (pH 8.0) and $100 \mathrm{mM} \mathrm{NaCI}$ ) were added. Pellets are resuspended afterwards. A total of $100 \mathrm{mM}$ PMSF and then $10 \mathrm{mg} / \mathrm{ml}$ lysozyme (Sigma) were added. The whole suspension was stirred. After that deoxycholic acid were subjoined. The suspension was stored at $37^{\circ} \mathrm{C}$ while stirring sporadically. When Lysate became viscous, $1 \mathrm{mg} / \mathrm{ml}$ DNase was added. Lysates have been incubated at $4^{\circ} \mathrm{C}$ overnight.

\section{SDS-PAGE and Western Blotting}

Initially, samples were mixed with 1x SDS loading buffer (50 mM Tris-Cl (pH 6.8), $100 \mathrm{mM}$ dithiothreitol, $2 \%(\mathrm{w} / \mathrm{v})$ SDS, $0.1 \%$ bromophenol blue, and 10\% (v/v) glycerol), and they were then boiled. SDS-PAGE was prepared with 15\% separating gel and 5\% stacking gel. After running 
the SDS-PAGE, the gels were stained with Coomassie Brilliant Blue. Having samples run on 15\% SDS-polyacrylamide gels, they were transferred onto Nitrocellulose membrane. Chimeric proteins were marked by Monoclonal Anti-polyHistidine-Peroxidase (Sigma, A7058) at a dilution of 1:2000. The expressed proteins were confirmed using $\mathrm{H} 2 \mathrm{O} 2$, and diaminobenzidine generated a brown precipitate.

Purification with 6\% Nickel-IDA Agarose

Ten bed volumes of Binding buffer (50mM NaH2Po4, 300mM NaCl, $10 \mathrm{mM}$ imidazole, Urea 8M, $\mathrm{pH}: 7)$ were added and mixed thoroughly at $4^{\circ} \mathrm{c}$ overnight on a rotator. Having removed supernatant, E. coli lysate was added to gel and incubated at $4^{\circ} \mathrm{c}$ overnight. Binding buffer was added 10 bed volumes and mixed gently on a rotatory shaker. The washing step (50mM NaH2Po4, 300mM NaCl, $20 \mathrm{mM}$ imidazole, Urea 8M, pH:7) was repeated 4 times and $1.5 \%$ Tween 20 was added to further reduce contamination. Suspensions were centrifuged at $500 \mathrm{~g}$ for 5 minutes to sediment agarose. One bed volume of elution buffer (50mM NaH2Po4, 300mM NaCl, $250 \mathrm{mM}$ imidazole, Urea 8M, pH=7) was added and mixed gently on a rotatory shaker. This suspension was centrifuged at $500 \mathrm{~g}$ for 5 minutes and his-taged protein containing supernatant was transferred into new tube and stored on ice. After that, imidazole was removed by dialysis.

Post-translational modification was performed by Tyrosinase (from mushroom). To study adhesion, purified recombinant unmodified proteins of Mgfp-5-GvpA, GvpA-Mfp-3 and copolymer have been resolved in 5\% acetic acid to halt auto-oxidation of DOPA residues and 25 $\mathrm{mM}$ ascorbic acid-containing buffer and have been modified with 10-unit mushroom tyrosinase to create DOPA at room temperature for $6 \mathrm{~h}$ at $\mathrm{pH}=6.5(17)$. BSA (18) and Cell-Tak were selected for negative and positive control respectively. 
Self-assembly of Mfp-5-GvpA and GvpA-Mfp-3:

After purification of Mfp-5-GvpA and Gvp-A-Mfp-3, protein concentration was measured by the bicinchoninic acid (BCA) assay. In phosphate solutions $(\mathrm{pH}=7)$, these proteins $(45 \mu \mathrm{M})$ were dissolved in. Then, $\mathrm{pH}$ was changed to $\mathrm{pH}=5$. Following that, these proteins were stored overnight at $4^{\circ}$ c. Two chimeric proteins were incubated with a variety of molar ratios.

Nitroblue tetrazolium (NBT) used for staining Dopa-containing proteins:

Acid-urea PAGE was performed to validate the presence of DOPA residues with redox cycling staining involving nitroblue tetrazolium (NBT) and glycinate of modified purified recombinant Mfp-5-GvpA, GvpA-Mfp-3 and (Mfp-5-GvpA:GvpA-Mfp-3)(19).

Acid-borate Difference Spectrum: a quantitative test to confirm DOPA

Evaluation of the amount of dopa in modified mussel-inspired adhesives was performed by Acidborate difference spectrum(20). Absorbance of DOPA in acid conditions is $280 \mathrm{~nm}$. Wavelengths were changed by the creation of diol-borate at $\mathrm{pH}=7-12(287 \mathrm{~nm})$.

Molarity of tyrosine in unmodified adhesives was measured: (n: the number of Tyrosine in unmodified adhesive proteins)

$\mathrm{n} \times$ (protein concentration in BCA assay)/ (Molecular weight of unmodified adhesive proteins)

M(Tyr) for GvpA-Mfp-3: 0.77252635(mM), M(Tyr) for Mfp-5-GvpA:0.7944(mM)

DOPA concentration was measured by Acid-borate difference spectrum

M DOPA for GvpA-Mfp-3: 0.09538(mM), M DOPA for GvpA-Mfp-5: 0.08973(mM)

Congo Red Assay 
The nitrocellulose membranes were used for spotting $50 \mu \mathrm{g} / \mathrm{mL}$ bio-inspired adhesive samples. After that, membranes with associated proteins were saturated in $0.0025(\mathrm{~m} / \mathrm{v} \%)$ Congo red solution for 1 hour at RT. After washing with water, these membranes were incubated overnight.

Adhesion Force Measurement:

Adhesion force between our chimeric adhesion proteins on mica surface and colloidal probe (Silica) was measured by Atomic Force Spectroscopy (AFS)(21). AFM force measurements were conducted at room temperature with varied $\mathrm{pH}$ values in buffered solutions $(\mathrm{pH}=2.5,5.0,7.0$ and 12.0) using an AFM5100N (HITACHI). Adhesion force measurements were performed at a rate of 0.2 to $2.3 \mathrm{~Hz}$, using Silica cantilever (coated with glass sphere). Afterwards, the force curves were analyzed by Hitachi Navigation system and Origin 8.1 software. Then, $45 \mu \mathrm{M}$ bio-inspired adhesive solution was covered on a mica surface under wet environment with different $\mathrm{pH}$ values $(\mathrm{pH}=2.5,5.0,7.0$ or 12.0$)$ for $1 \mathrm{~h}$ to completely cover mica surfaces. A total of 64 measurements were conducted for each adhesive fibre type. In the end, adhesion forces have been measured as reported by the Johnson-Kendall-Roberts(22):

$\mathrm{Fad}=3 \pi \mathrm{REad} \quad \mathrm{R}$ : Touch Radius $\mathrm{Ead}=$ Adhesion Energy per area

Authors' Contribution:

HI, SH, and SNH writing paper and data analysis. HHF and SZ data collecting. SB and MAS conceptualization, Investigation, Formal analysis, Writing-review \& editing. All co-authors commented on the manuscript. All authors read and approved the final manuscript.

Acknowledgments: 
This research work was supported by Pasteur Institute of Iran and Iran National Science Foundation by grant No: 96016699 . Also, it was financially supported by grant No: 961207 from the Biotechnology Development Council of the Islamic Republic of Iran. We acknowledged Mr. Saadi Hosseini and Mrs. Neda Moazzezy for providing proof reading the article. 


\section{References:}

1 Stewart, R. J., Wang, C. S. \& Shao, H. Complex coacervates as a foundation for synthetic underwater adhesives. Advances in colloid and interface science 167, 85-93 (2011).

2 Bré, L. P., Zheng, Y., Pêgo, A. P. \& Wang, W. Taking tissue adhesives to the future: from traditional synthetic to new biomimetic approaches. Biomaterials Science 1, 239-253 (2013).

3 Gu, J., Miao, S., Yan, Z. \& Yang, P. Multiplex binding of amyloid-like protein nanofilm to different material surfaces. Colloid and Interface Science Communications 22, 42-48 (2018).

4 Zhong, C. et al. Strong underwater adhesives made by self-assembling multi-protein nanofibres. Nature nanotechnology 9, 858 (2014).

5 Barlow, D. E. et al. Characterization of the adhesive plaque of the barnacle Balanus amphitrite: amyloid-like nanofibrils are a major component. Langmuir 26, 6549-6556 (2010).

6 Waite, J. H. Adhesion a la moule. Integrative and comparative biology 42, 1172-1180 (2002).

7 Li, Y., Qin, M., Li, Y., Cao, Y. \& Wang, W. Single molecule evidence for the adaptive binding of DOPA to different wet surfaces. Langmuir 30, 4358-4366 (2014).

8 Danner, E. W., Kan, Y., Hammer, M. U., Israelachvili, J. N. \& Waite, J. H. Adhesion of mussel foot protein Mefp-5 to mica: an underwater superglue. Biochemistry 51, 6511-6518 (2012).

9 Li, C., Qin, R., Liu, R., Miao, S. \& Yang, P. Functional amyloid materials at surfaces/interfaces. Biomaterials science 6, 462-472 (2018).

10 Knowles, T. P. \& Mezzenga, R. Amyloid fibrils as building blocks for natural and artificial functional materials. Advanced Materials 28, 6546-6561 (2016).

11 Chiti, F. \& Dobson, C. M. Protein misfolding, functional amyloid, and human disease. Annu. Rev. Biochem. 75, 333-366 (2006).

12 Knowles, T. P., Oppenheim, T. W., Buell, A. K., Chirgadze, D. Y. \& Welland, M. E. Nanostructured films from hierarchical self-assembly of amyloidogenic proteins. Nature Nanotechnology 5, 204-207 (2010).

13 Knowles, T. P. \& Buehler, M. J. Nanomechanics of functional and pathological amyloid materials. Nature nanotechnology 6, 469-479 (2011).

14 Bayro, M. J., Daviso, E., Belenky, M., Griffin, R. G. \& Herzfeld, J. An amyloid organelle, solidstate NMR evidence for cross- $\beta$ assembly of gas vesicles. Journal of Biological Chemistry 287, 3479-3484 (2012).

15 Aich, P. et al. Self-assembled adhesive biomaterials formed by a genetically designed fusion protein. Chemical Communications 54, 12642-12645 (2018).

16 Kim, E. et al. Microbially synthesized repeats of mussel foot protein display enhanced underwater adhesion. ACS applied materials \& interfaces 10, 43003-43012 (2018).

17 Dumon-Seignovert, L., Cariot, G. \& Vuillard, L. The toxicity of recombinant proteins in Escherichia coli: a comparison of overexpression in BL21 (DE3), C41 (DE3), and C43 (DE3). Protein expression and purification 37, 203-206 (2004).

18 Narayanan, A., Ridilla, M. \& Yernool, D. A. Restrained expression, a method to overproduce toxic membrane proteins by exploiting operator-repressor interactions. Protein Science 20, 51-61 (2011).

19 Grodberg, J. \& Dunn, J. J. ompT encodes the Escherichia coli outer membrane protease that cleaves T7 RNA polymerase during purification. Journal of bacteriology 170, 1245-1253 (1988).

20 Studier, F. W. \& Moffatt, B. A. Use of bacteriophage T7 RNA polymerase to direct selective highlevel expression of cloned genes. Journal of molecular biology 189, 113-130 (1986). 
21 Hwang, D. S., Yoo, H. J., Jun, J. H., Moon, W. K. \& Cha, H. J. Expression of functional recombinant mussel adhesive protein Mgfp-5 in Escherichia coli. Applied and environmental microbiology 70, 3352-3359 (2004).

$22 \mathrm{Li}$, Y. et al. Hidden complexity of synergistic roles of Dopa and lysine for strong wet adhesion. Materials Chemistry Frontiers 1, 2664-2668 (2017).

23 Maier, G. P., Rapp, M. V., Waite, J. H., Israelachvili, J. N. \& Butler, A. Adaptive synergy between catechol and lysine promotes wet adhesion by surface salt displacement. Science 349, 628-632 (2015).

24 Wilker, J. J. Positive charges and underwater adhesion. Science 349, 582-583 (2015).

25 Smith, A. M. \& Scheibel, T. Functional amyloids used by organisms: a lesson in controlling assembly. Macromolecular Chemistry and Physics 211, 127-135 (2010).

26 Wei, W., Yu, J., Broomell, C., Israelachvili, J. N. \& Waite, J. H. Hydrophobic enhancement of dopa-mediated adhesion in a mussel foot protein. Journal of the American Chemical Society 135, 377-383 (2013).

27 Bilotto, P. et al. Adhesive Properties of Adsorbed Layers of Two Recombinant Mussel Foot Proteins with Different Levels of DOPA and Tyrosine. Langmuir 35, 15481-15490 (2019).

28 Hayes, P. K., Walsby, A. E. \& Walker, J. E. Complete amino acid sequence of cyanobacterial gasvesicle protein indicates a 70-residue molecule that corresponds in size to the crystallographic unit cell. Biochemical journal 236, 31-36 (1986).

29 Yang, B. et al. In vivo residue-specific dopa-incorporated engineered mussel bioglue with enhanced adhesion and water resistance. Angewandte Chemie 126, 13578-13582 (2014).

30 Kim, S. et al. Complexation and coacervation of like-charged polyelectrolytes inspired by mussels. Proceedings of the National Academy of Sciences 113, E847-E853 (2016).

31 Zeng, H., Hwang, D. S., Israelachvili, J. N. \& Waite, J. H. Strong reversible Fe3+-mediated bridging between dopa-containing protein films in water. Proceedings of the National Academy of Sciences 107, 12850-12853 (2010). 


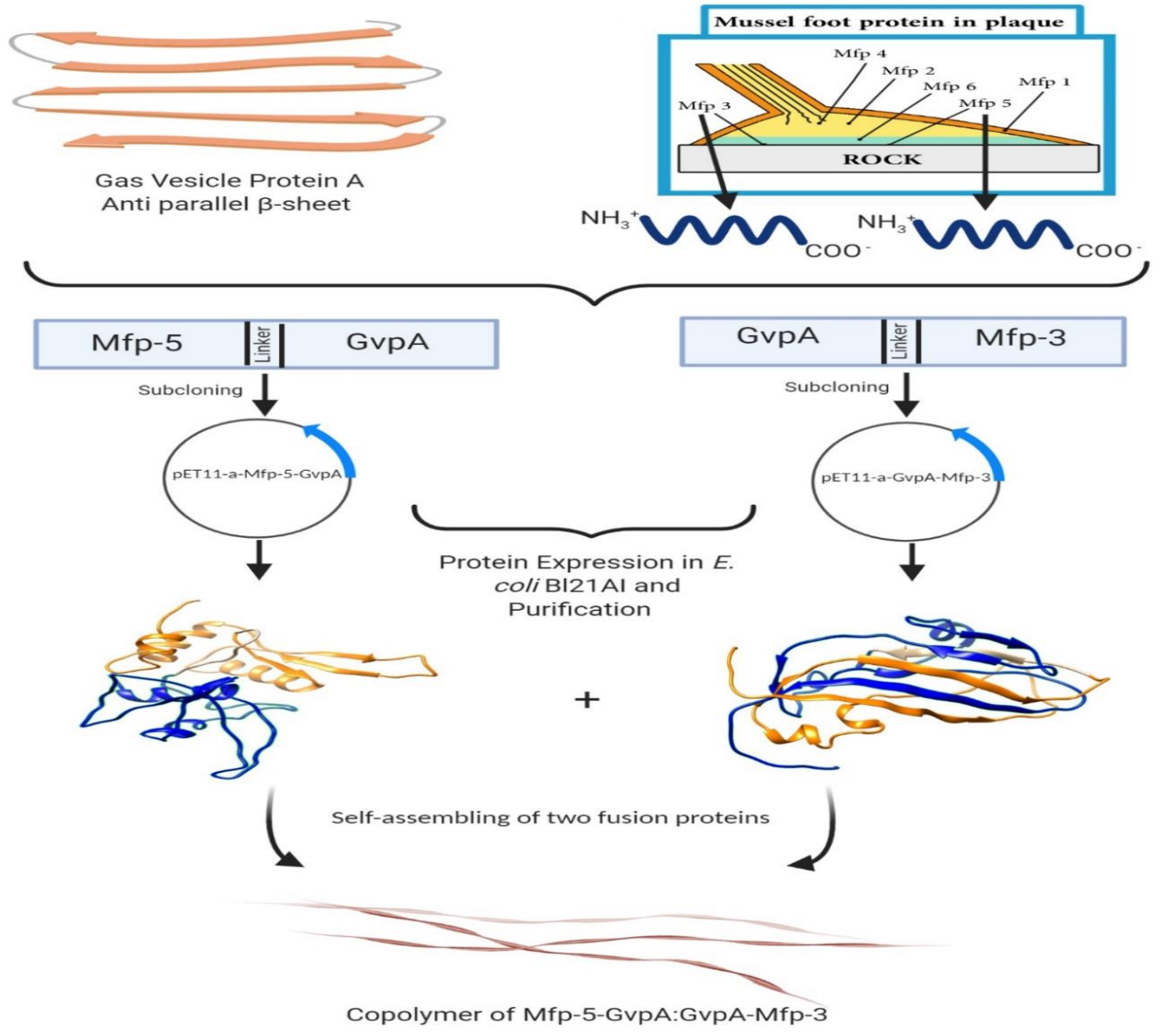

Figure 1: Genetic engineering of fusion proteins, expression and self-assembling of Mfp-5GvpA and GvpA-Mfp-3 conducted successfully (Created with BioRender.com). 

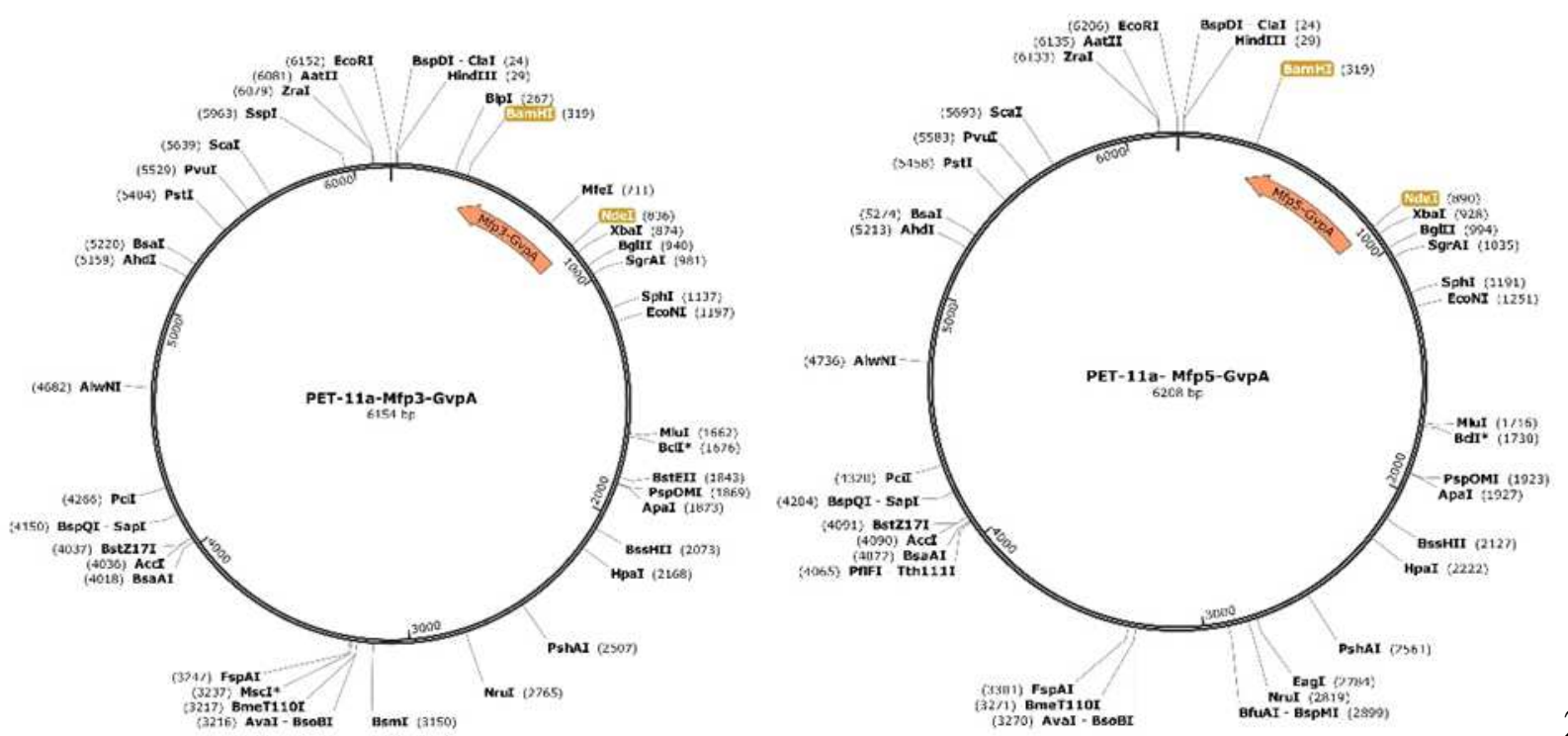

2-1-Gene constructs:

Figure 2: Pet11a-Mfp-5-GvpA and Mfp-3-GvpA plasmid constructions. Gene sequences were located between BamHI and NdeI restriction sites. 


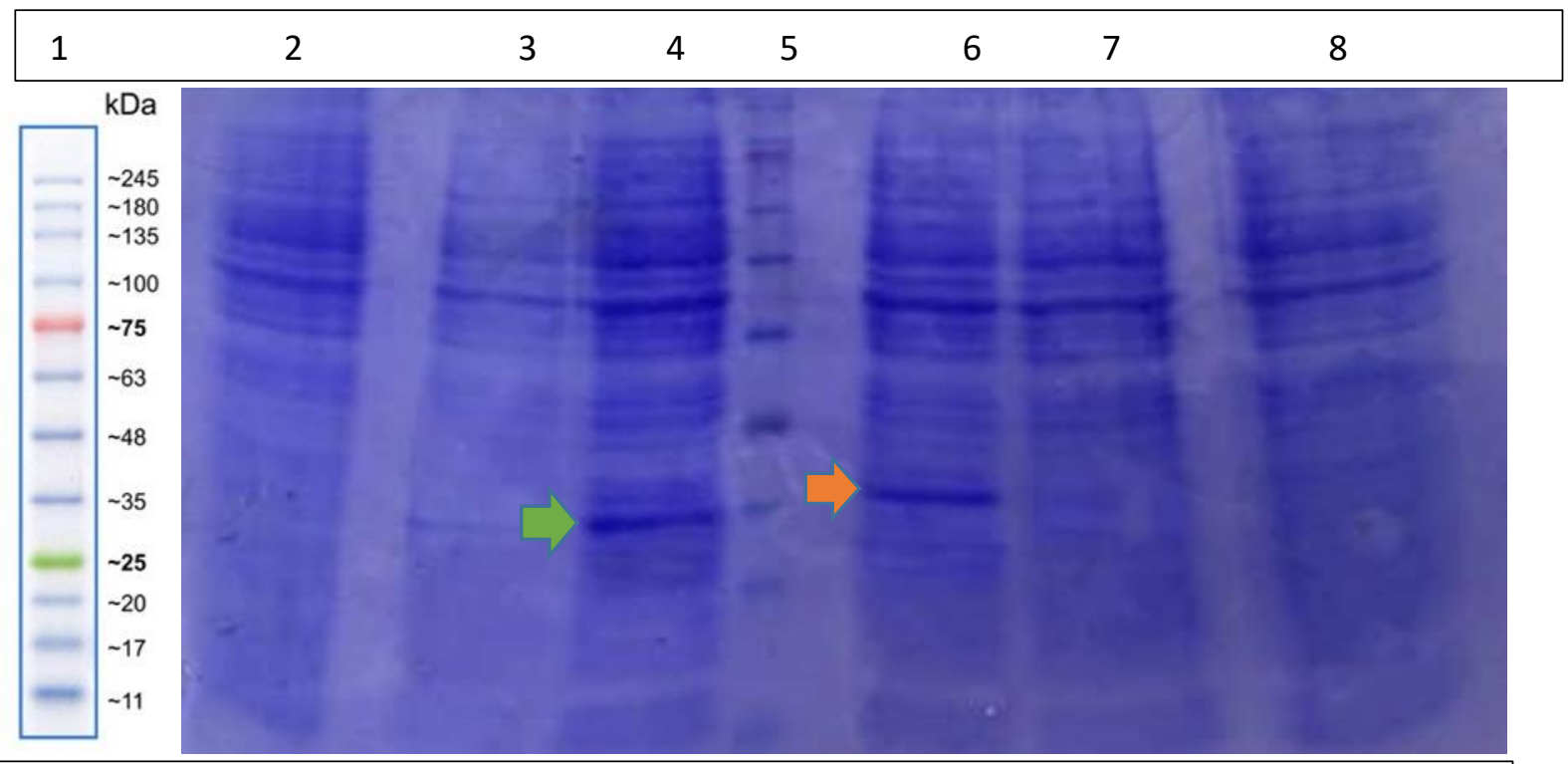

Figure 3: Over-expression of two bio-inspired amyloid adhesives were analyzed by SDSPAGE gel with G250 staining:1) Protein marker, 2,8) Induction of $E$. coli Bl21 AI with Plasmid without gene 3,7) Induction of E. coli Bl21 AI without plasmid 4) Expressed Mfp3-GvpA (Green arrow) with M.W: 18279.44 Da 6) Expressed GvpA-Mfp-5 (Orange arrow) with M.W=20371.22 Da 5) Protein marker. 


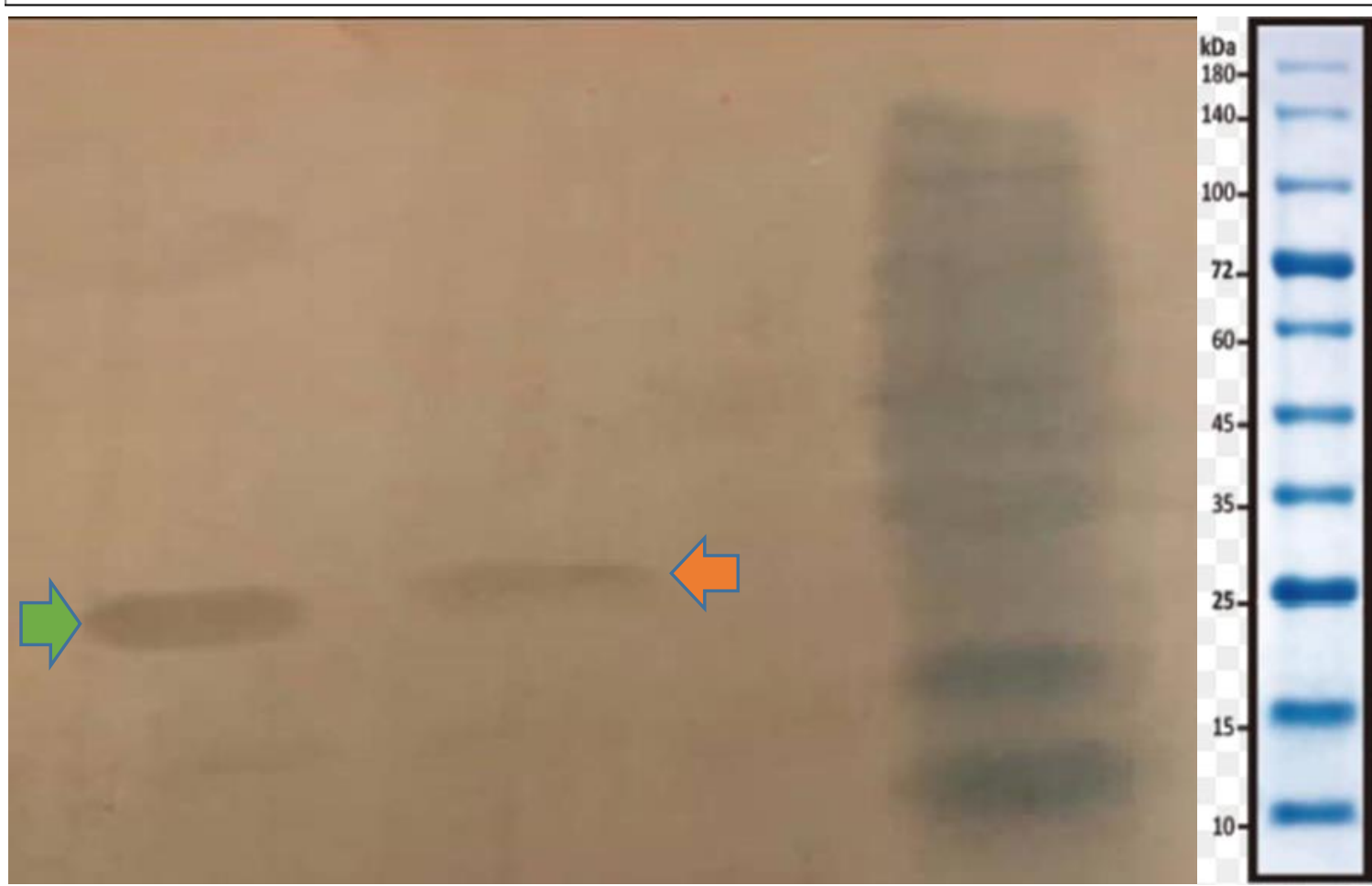

Figure 4: Protein expression confirmed by Western Blotting method through antihistag antibody. Line 1 and 2: Protein marker, Line 3: GvpA-Mfp-5 (Orange arrow), Line 4: Mfp-3-GvpA (Green arrow). 


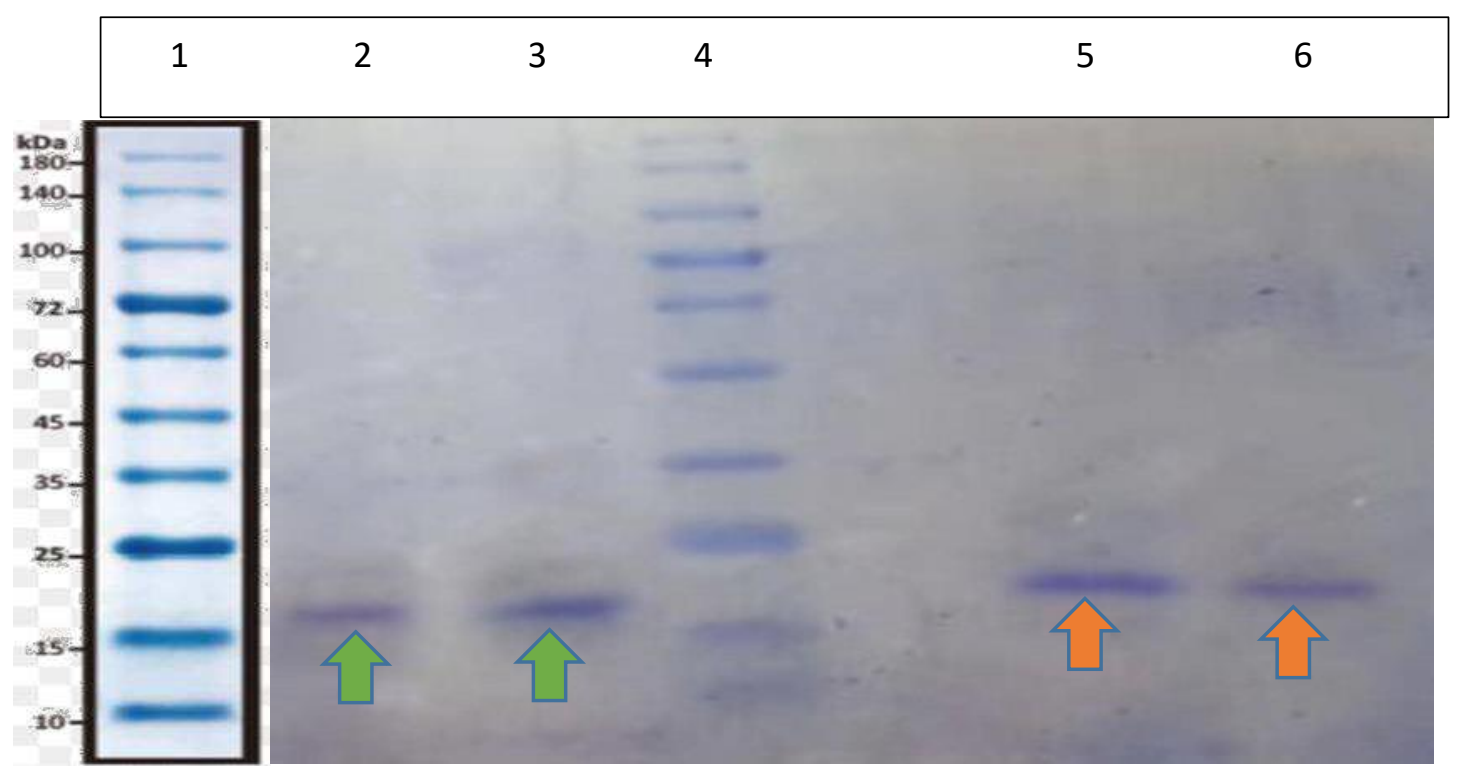

Figure 5: SDS-PAGE analysis: Protein purification by Immunoaffinity purification; Lane 1 and 4 protein markers; Lane 5 and 6: GvpA-Mfp-5(Orange arrow); Lane 2, 3: Mfp-3-GvpA(Green arrow) respectively.

\begin{tabular}{|l|l|l|}
\cline { 2 - 3 } \multicolumn{1}{c|}{} & GvpA-Mfp3 & Mfp5-GvpA \\
\hline DOPA quantity (\%) & $63.7 \% \pm 2.4$ & $74.3 \% \pm 3.8$ \\
\hline Table 1: ABDS analysis: measurement of DOPA content in GvpA-Mfp-3 and Mfp-5-GvpA. \\
\hline
\end{tabular}



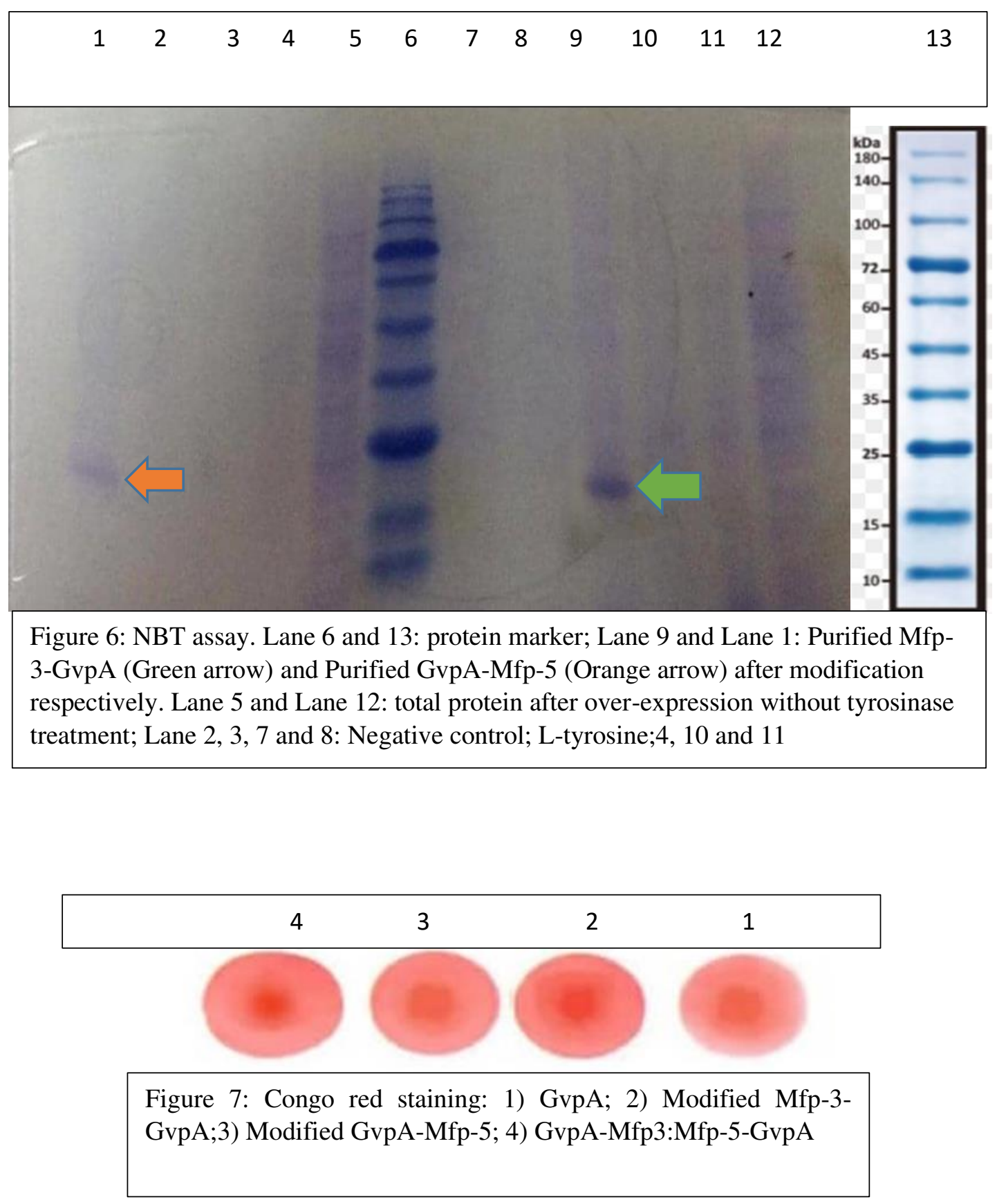


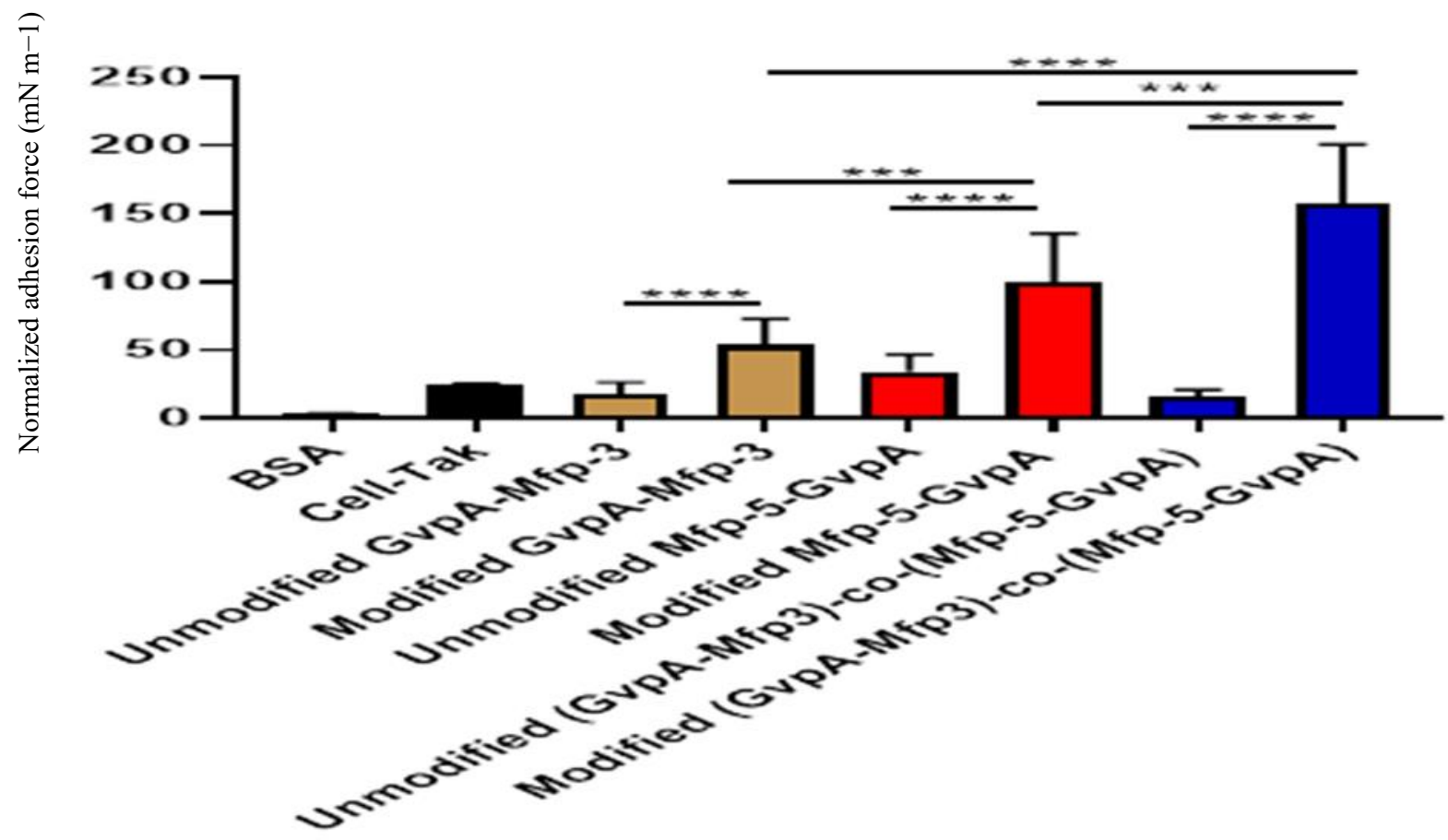

Figure 8: Adhesion force of bioadhesives with silica tip: This figure demonstrates comparison of adhesion force $\left(\mathrm{mNm}^{-1}\right)$ between mussel-inspire adhesives: Unmodified and modified GvpA-mfp-3, mfp-5-GvpA and (Gvp-A-Mfp3)-co-(Mfp-5-GvpA) copolymer. ${ }^{* * *} \mathrm{P} \leq 0.001,{ }^{* * * *} \mathrm{P} \leq 0.0001$ 


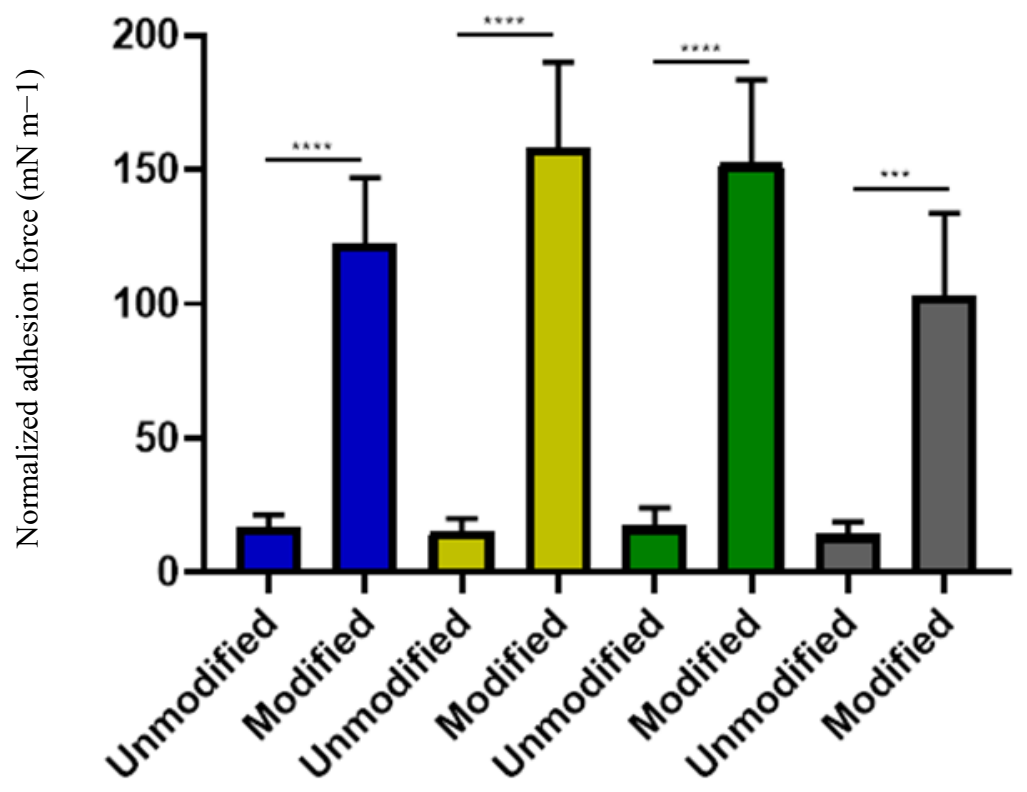

\section{$\mathrm{PH}=2.5 \quad \mathrm{PH}=5 \quad \mathrm{PH}=7 \quad \mathrm{PH}=12$}

Figure 9: Adhesion force of (Gvp-A-Mfp3)-co-(Mfp-5-GvpA) copolymer at different $\mathrm{pH}$ values: As shown in this figure, in $\mathrm{pH}=5$ (Yellow Colour) and $\mathrm{pH}=7$ (Green Colour) copolymers have the most force adhesion respectively.

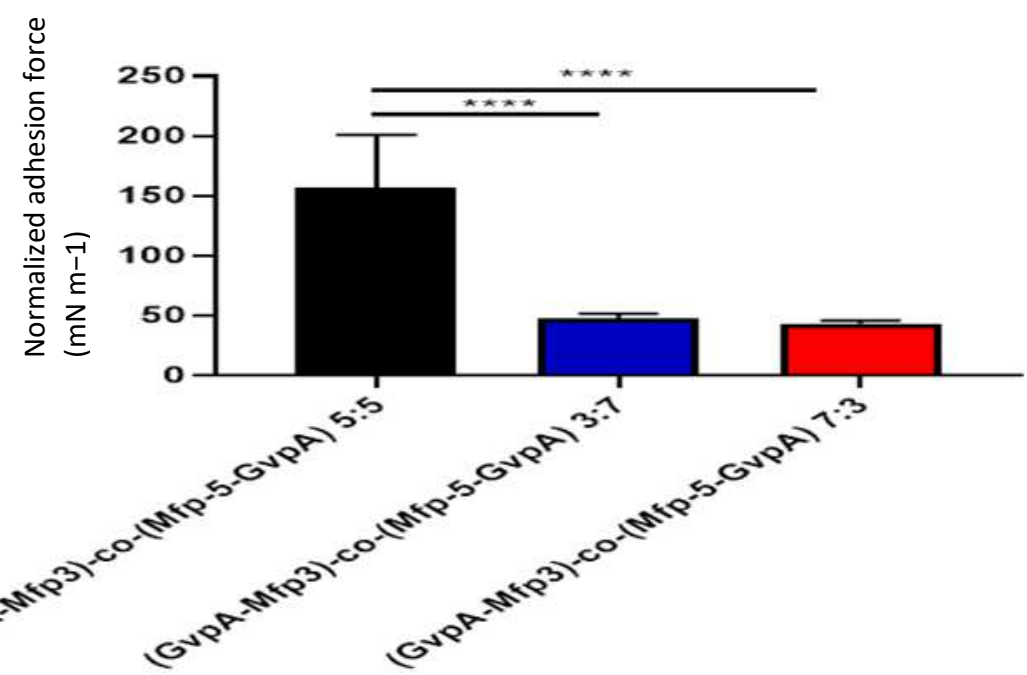

Figure 10: Comparison of adhesion force between copolymer hybrids (GvpA-Mfp3:GvpA-Mfp-5) with 3 ratios. molar ratio, 5:5(157.1937 $\mathrm{mN} / \mathrm{m}): 3: 7(47.8312 \mathrm{mN} / \mathrm{m}): 7: 3(43.5175 \mathrm{mN} / \mathrm{m})$. 


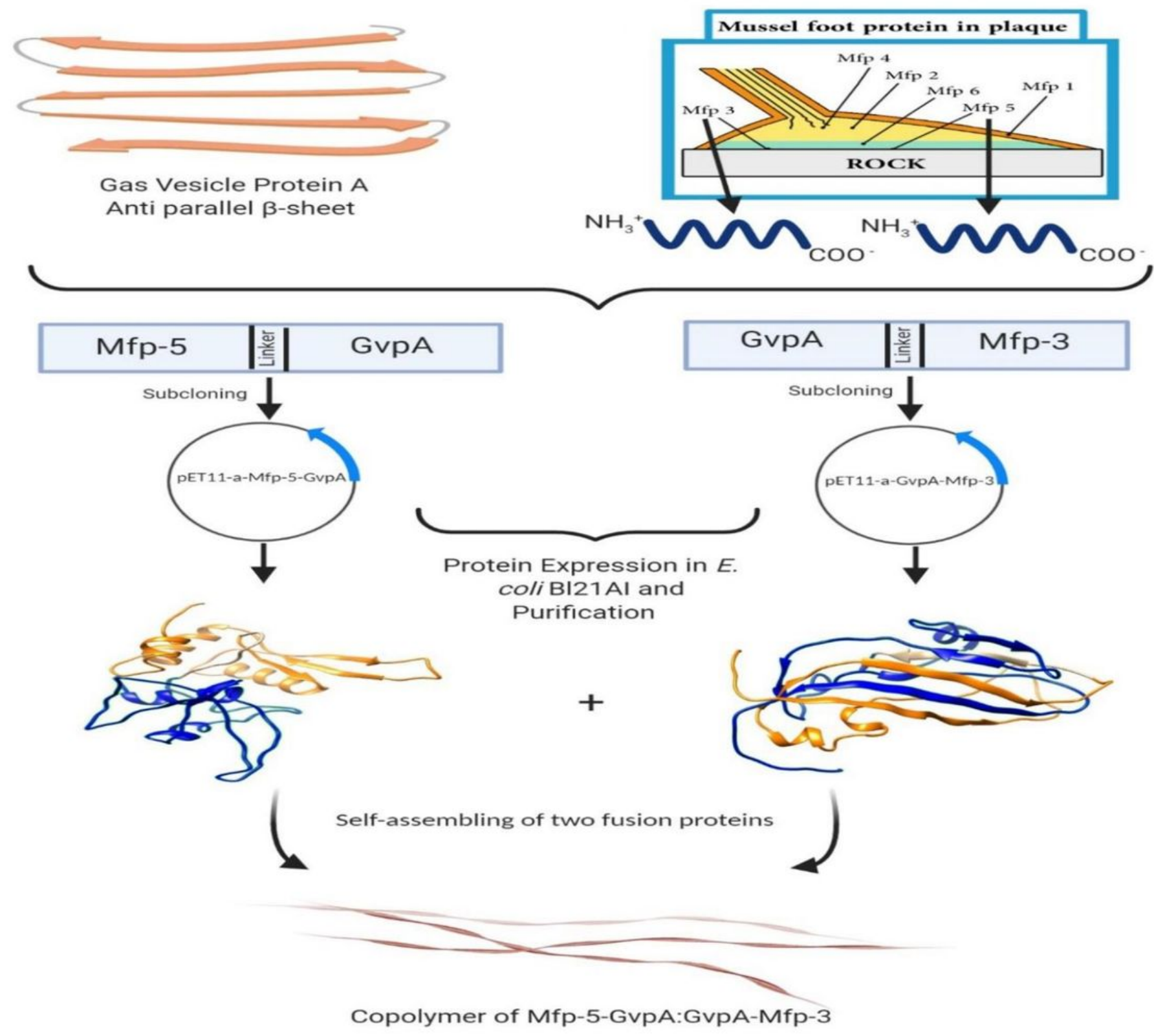

\section{Figure 1}

Genetic engineering of fusion proteins, expression and self-assembling of Mfp-5- GvpA and GvpA-Mfp-3 conducted successfully (Created with BioRender.com). 

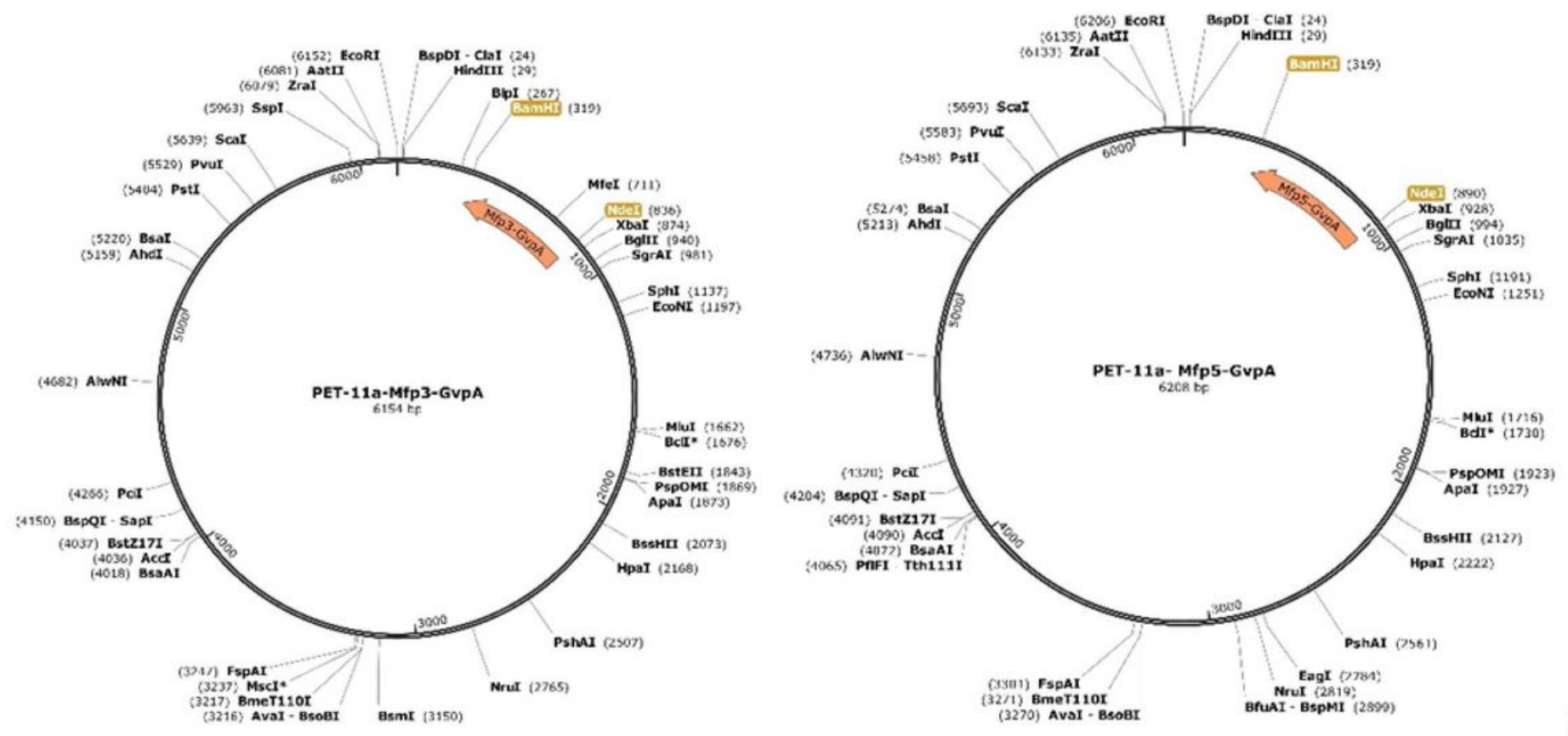

\section{2-1-Gene constructs:}

Figure 2

Please see the Manuscript PDF file for the complete figure caption

\begin{tabular}{|c|c|c|c|c|c|c|c|c|}
\hline 1 & & 2 & 3 & 4 & 5 & 6 & 7 & 8 \\
\hline & $\mathrm{kDa}$ & & & & & & & \\
\hline$\longrightarrow$ & $\sim 245$ & & & & & & & \\
\hline$\longrightarrow$ & $\sim 180$ & & & & & & & \\
\hline$\square$ & $\sim 135$ & & & & & & & \\
\hline 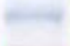 & $\sim 100$ & & & & & & & \\
\hline 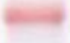 & $\sim 75$ & & & & $=$ & & & \\
\hline- & $\sim 63$ & & & & & & & \\
\hline- & $\sim 48$ & & & & & & & \\
\hline- & $\sim 35$ & & & & & 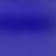 & & \\
\hline$=$ & $\sim 25$ & & & & & & & \\
\hline$=$ & $\sim 20$ & & & & & & & \\
\hline$=$ & $\sim 17$ & & & & & & & \\
\hline$=$ & $\sim 11$ & & & & & e & & \\
\hline
\end{tabular}

Figure 3

Over-expression of two bio-inspired amyloid adhesives were analyzed by SDS-PAGE gel with G250 staining:1) Protein marker, 2,8) Induction of E. coli BI21 Al with Plasmid without gene 3,7) Induction of E. 
coli Bl21 Al without plasmid 4) Expressed Mfp®3-GvpA (Green arrow) with M.W: 18279.44 Da 6) Expressed GvpA-Mfp-5 (Orange arrow) with M.W=20371.22 Da 5) Protein marker.

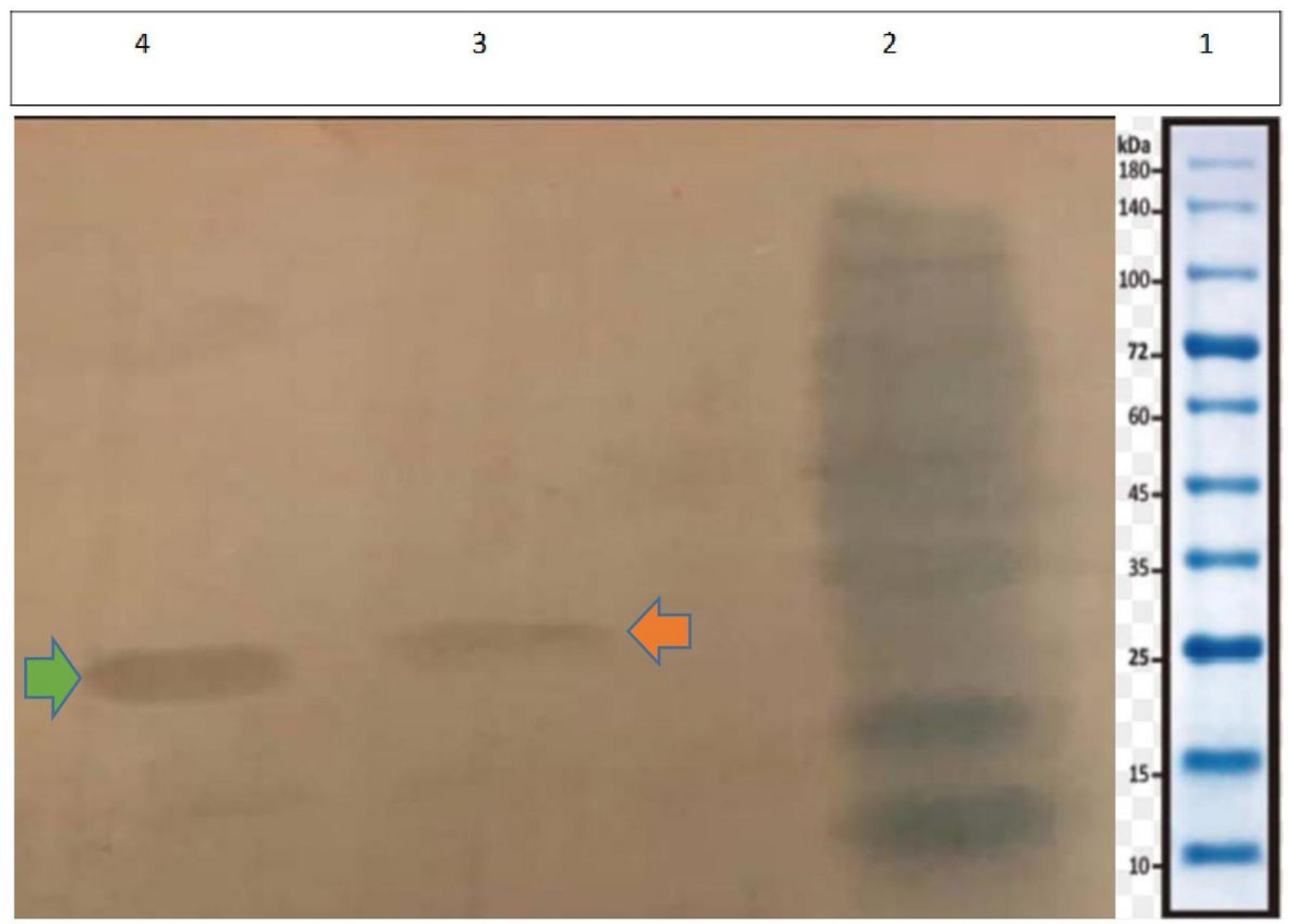

Figure 4

Protein expression confirmed by Western Blotting method through anti-histag antibody. Line 1 and 2: Protein marker, Line 3: GvpA-Mfp-5 (Orange arrow), Line 4: Mfp-3-GvpA (Green arrow). 


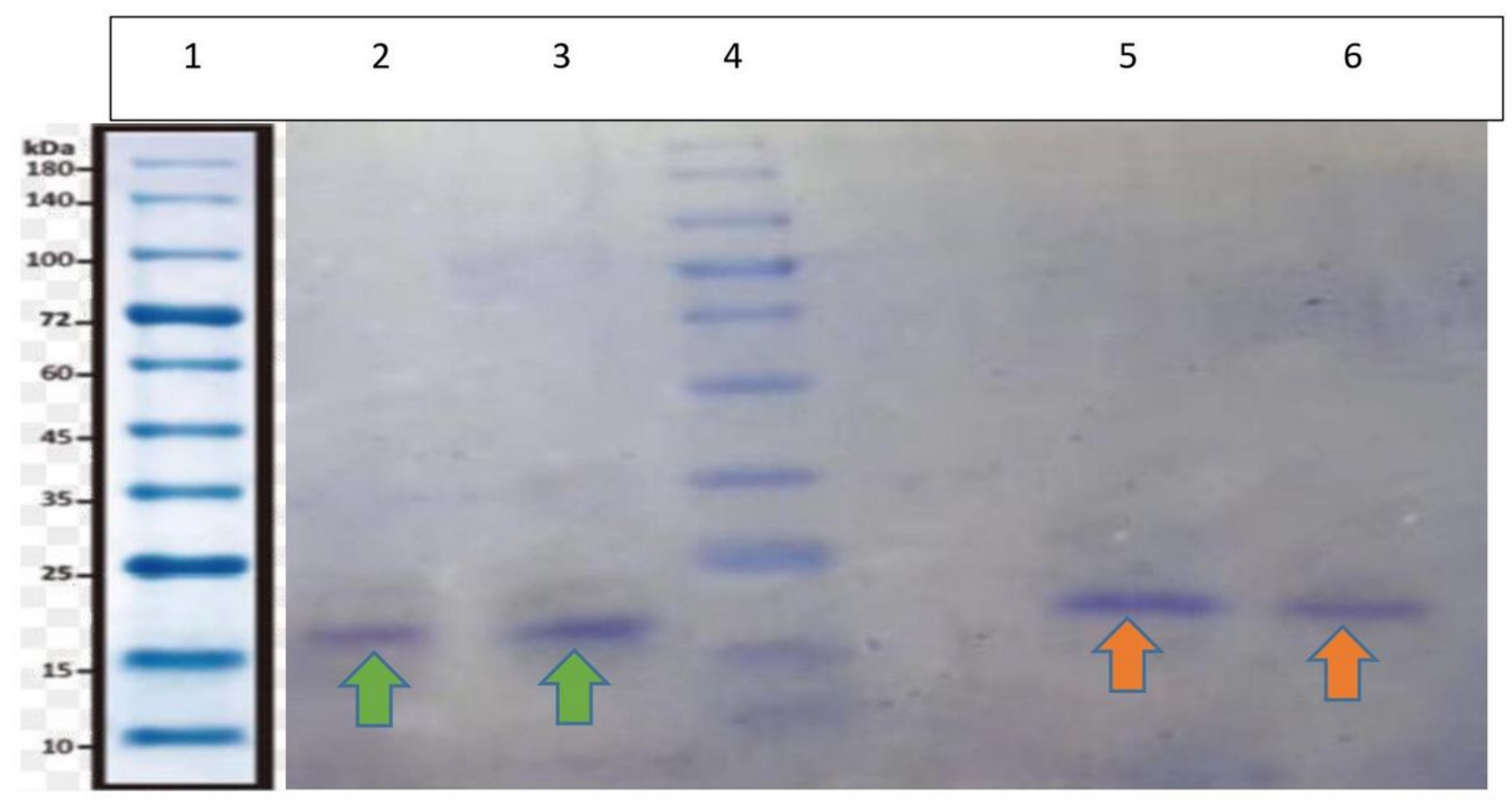

Figure 5

SDS-PAGE analysis: Protein purification by Immunoaffinity purification; Lane 1 and 4 protein markers; Lane 5 and 6: GvpA-Mfp-5(Orange arrow); Lane 2, 3: Mfp-3-GvpA(Green arrow) respectively. 


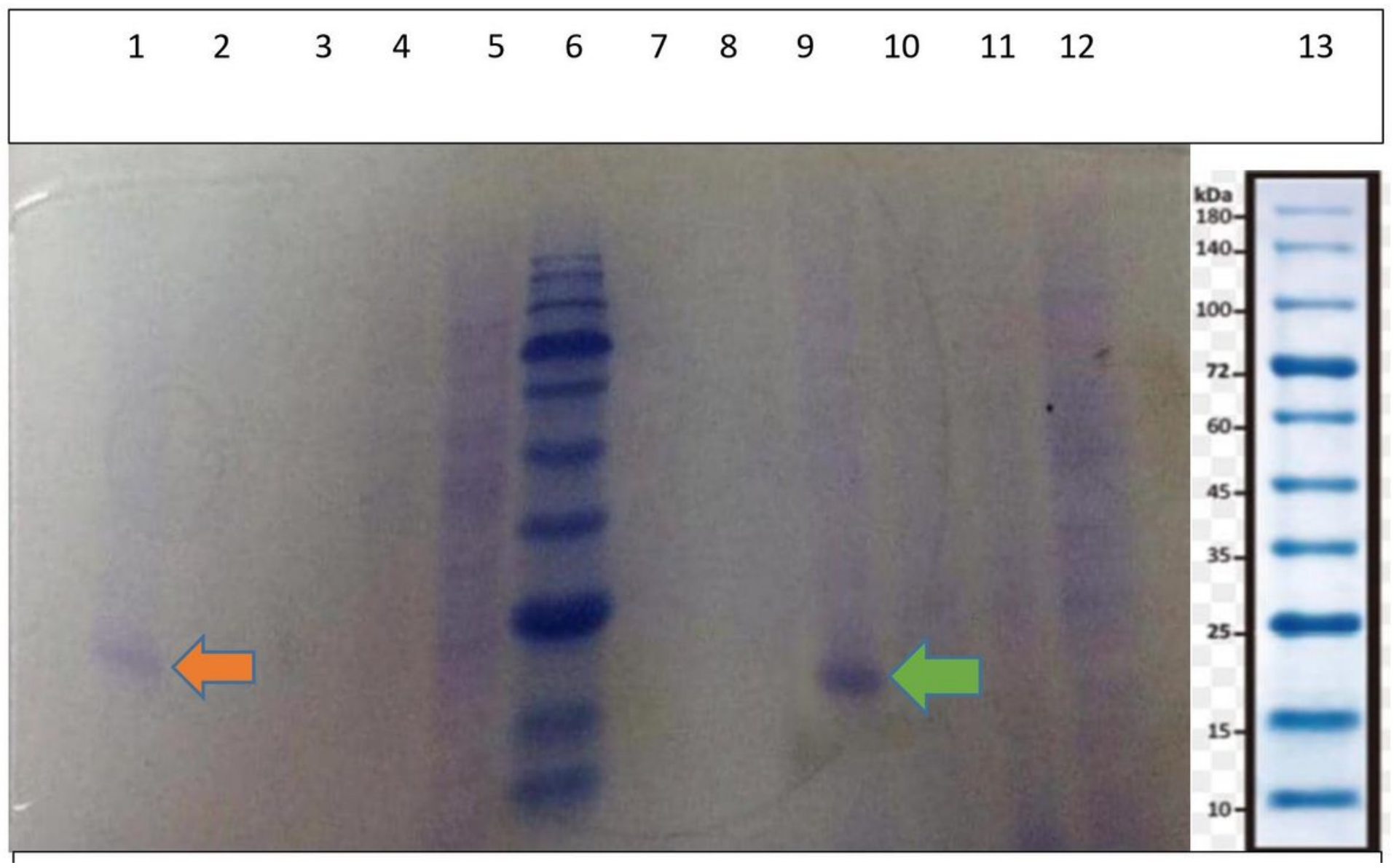

Figure 6

NBT assay. Lane 6 and 13: protein marker; Lane 9 and Lane 1: Purified Mfp-3-GvpA (Green arrow) and Purified GvpA-Mfp-5 (Orange arrow) after modification respectively. Lane 5 and Lane 12: total protein after over-expression without tyrosinase treatment; Lane 2, 3, 7 and 8: Negative control; L-tyrosine;4, 10 and 11

\begin{tabular}{|lllll|}
\hline 4 & 3 & 2 & 1 \\
\hline
\end{tabular}

Figure 7

Congo red staining: 1) GvpA; 2) Modified Mfp-3- GvpA;3) Modified GvpA-Mfp-5; 4) GvpA-Mfp3:Mfp-5GvpA 


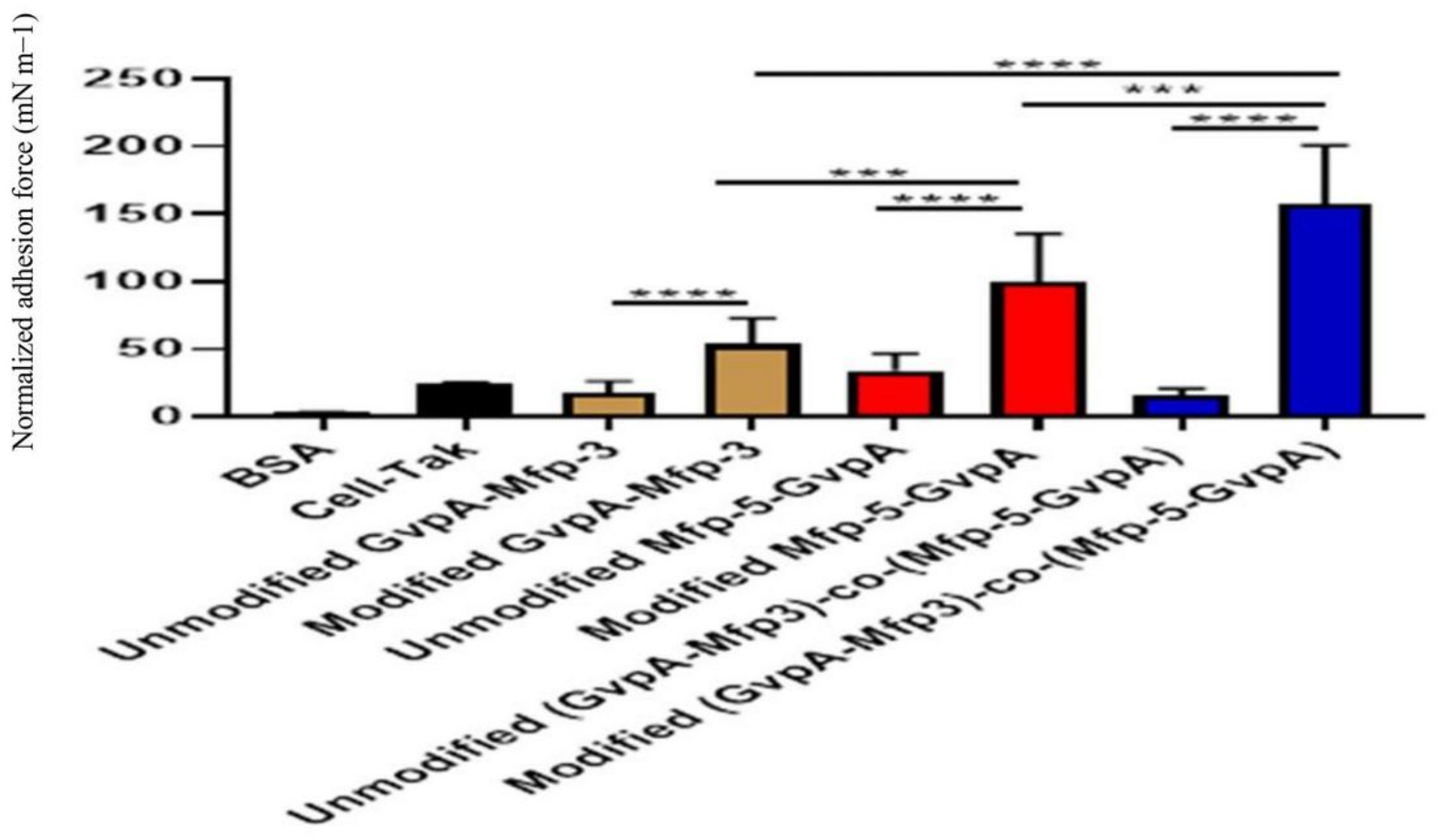

Figure 8

Adhesion force of bioadhesives with silica tip: This figure demonstrates comparison of adhesion force ( $\mathrm{mNm}-1$ ) between mussel-inspire adhesives: Unmodified and modified GvpA-mfp-3, mfp-5-GvpA and (Gvp-A-Mfp3)-co-(Mfp-5-GvpA) copolymer. ${ }^{\star \star \star *} \mathrm{P} \leq 0.001,{ }^{\star \star \star \star *} \mathrm{P} \leq 0.0001$ 


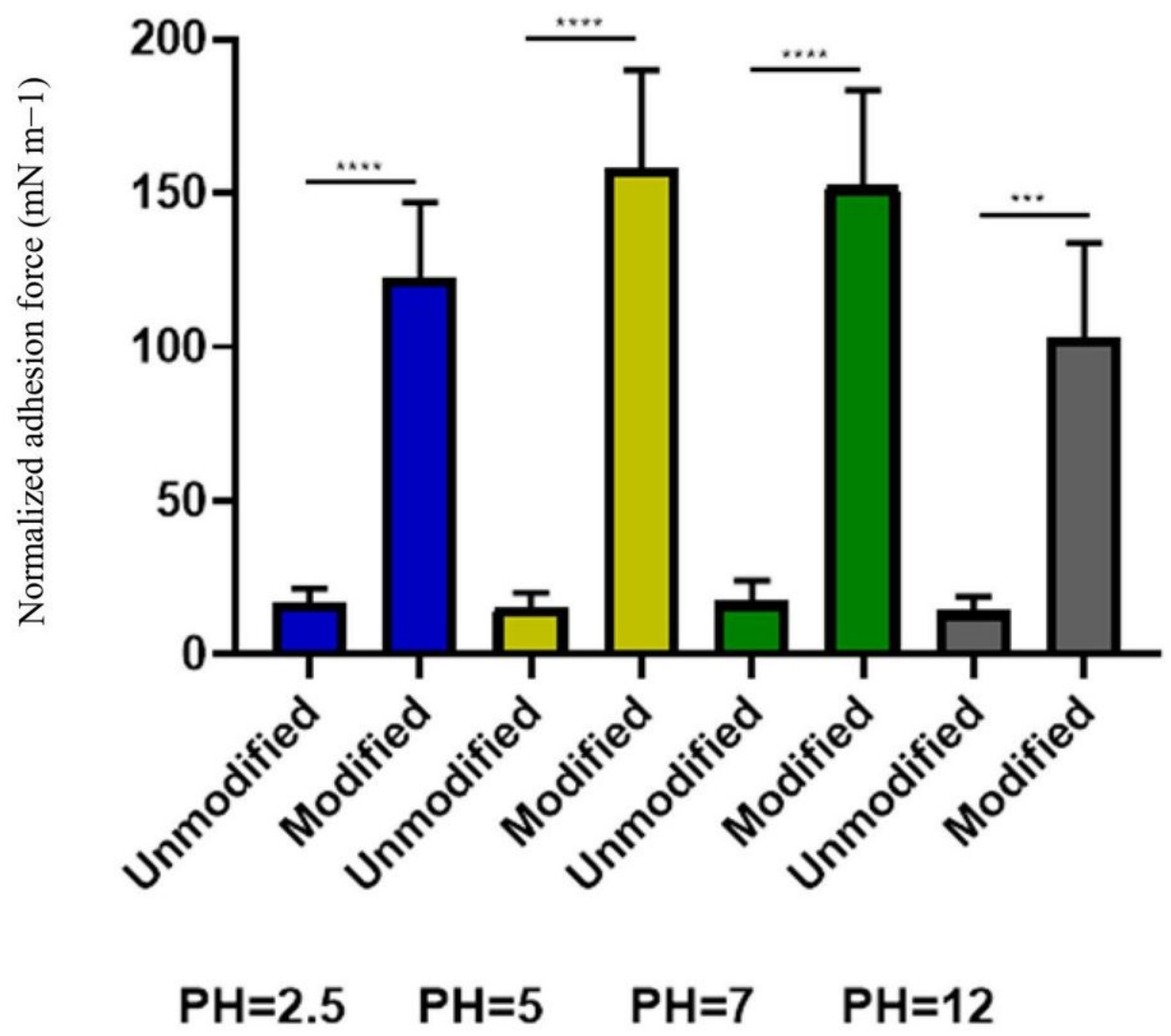

Figure 9

Adhesion force of (Gvp-A-Mfp3)-co-(Mfp-5-GvpA) copolymer at different pH values: As shown in this figure, in $\mathrm{pH}=5$ (Yellow Colour) and $\mathrm{pH}=7$ (Green Colour) copolymers have the most force adhesion respectively. 


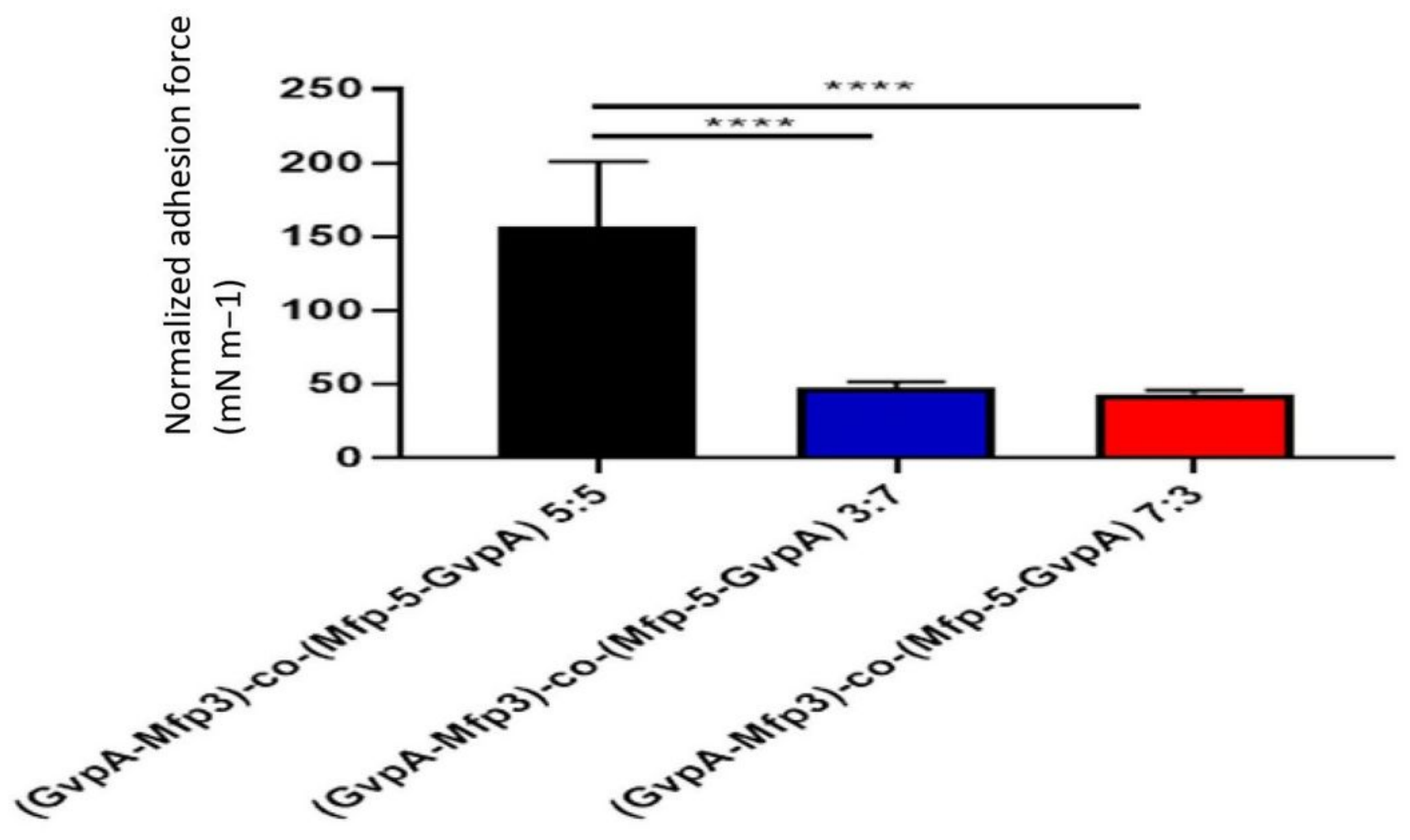

Figure 10

Comparison of adhesion force between copolymer hybrids (GvpA-Mfp3:GvpA-Mfp-5) with 3 ratios. molar ratio, 5:5(157.1937 mN/m);3:7(47.8312 mN/m); 7:3(43.5175mN/m)

\section{Supplementary Files}

This is a list of supplementary files associated with this preprint. Click to download.

- supplementaryinformation.pdf 